\title{
Isolation and Characterization of Bacteriophages Active against Stalked Bacteria
}

\author{
BY JEAN M. SCHMIDT AND R. Y. STANIER \\ Department of Bacteriology, University of California, Berkeley, \\ California, U.S.A.
}

(Received 3 October 1964)

\begin{abstract}
SUMMARY
The isolation and properties of 23 phages lytic for stalked bacteria of the genera Caulobacter and Asticcacaulis are described. They fall into seven groups on the basis of host range and serological properties. Phages of groups I-VI attack only Caulobacter species; those of group VII, only Asticcacaulis. Groups I-III comprise DNA viruses with long flexible tails and of unusually large size, the heads having dimensions of $50 \times 170$ $\mathrm{m} \mu$. Groups IV-VI comprise RNA viruses of simple structure, 21-23 $\mathrm{m} \mu$ in diameter. The specific Asticcacaulis phages (group VII) are tailed DNA viruses, similar in form and size to coliphage lambda. The implications of this study for the taxonomy of the caulobacters are discussed.
\end{abstract}

\section{INTRODUCTION}

Stalked bacteria of the genera Caulobacter and Asticcacaulis have recently been the subject of a monograph by Poindexter (1964). The consequent availability of an extensive series of strains led us to look for bacteriophages active against these distinctive bacteria. The present paper reports the isolation and general properties of a series of phages which cause lysis of Caulobacter or Asticcacaulis. After this investigation had been undertaken, a phage lytic for $C$. vibrioides, distinctly different from any described here, was reported by Khavina \& Rautenstein (1963).

\section{METHODS}

Media. The standard complex medium (PYE) of Poindexter (1964), consisting of $0.2 \%$ peptone, $0.1 \%$ yeast extract, and $0.00045 \mathrm{M}-\mathrm{MgSO}_{4} .7 \mathrm{H}_{2} \mathrm{O}$ in tap water was used for routine cultivation of Caulobacter and Asticcacaulis strains. This medium was satisfactory for the isolation and propagation of phages. The plating medium contained $1 \%$ agar. Phage adsorptions were conducted in PYE broth prepared with de-ionized water (in place of tap water) and containing 0.002 or $0.004 \mathrm{M}-\mathrm{MgSO}_{4}$, instead of the lower concentration used in the standard growth medium.

Bacterial strains. The Caulobacter and Asticcacaulis strains used in this investigation were obtained from the collection of Dr Jeanne S. Poindexter, and will be referred to by her designations (Poindexter, 1964). The $\mathrm{Hfr}$ and $\mathrm{F}^{-}$strains of Escherichia coli tested in host range specificity experiments were supplied by Susanne DeWitt.

Isolation of bacteriophages. An enrichment technique was used for isolation of 
phages from sewage, soil and pond water, since initial attempts to obtain such phages by direct plating were uniformly unsuccessful. Before setting up the enrichment cultures, sewage samples were usually exposed to $3 \%(v / v)$ chloroform to decrease the bacterial content. Equal volumes of sewage or pond water and broth cultures of the prospective host strains were incubated without shaking for periods ranging from 16 to $\mathbf{7 2} \mathrm{hr}$. Samples were then centrifuged to sediment bacteria, and the supernatant liquid filtered through a Millipore Type HA filter $(0.45 \mu)$. Dilutions of each filtrate were mixed with $5 \times 10^{8}$ colony-forming units of the presumptive host strain used in the enrichment, and overlayer plates were prepared. Plates were examined for plaques after 18- and 48-hr incubation periods at $30^{\circ}$. Pure phage clones were obtained by stabbing single plaques with a platinum needle, suspending the material in PYE broth, and replating a series of dilutions. The procedure was replated several times and single plaques were finally selected for the preparation of stock lysates.

\section{Table 1. Isolation of Caulobacter and Asticcacaulis phages}

\begin{tabular}{|c|c|c|}
\hline Phage & $\begin{array}{l}\text { Original host } \\
\text { (enrichment) }\end{array}$ & Source \\
\hline$\emptyset \mathrm{Cb} 1$ & C. bacteroides $11 \mathrm{a}$ & Chlorinated sewage \\
\hline ØCb 2 & C. vibrioides $\mathbf{H}$ & Chlorinated sewage \\
\hline$\emptyset \mathrm{Cb} 3$ & C. bacteroides $11 \mathrm{a}$ & Raw sewage no. 1 \\
\hline ØCb 4, 5 & C. vibrioides $\mathbf{\text { н }}$ & Raw sewage no. 1 \\
\hline$\emptyset \mathrm{Cb} 6,7,8,9,10,11,19$ & C. bacteroides $11 \mathrm{a}$ & Raw sewage no. 2 \\
\hline ØCb 12 & C. vibrioides $\mathrm{H}$ & Contaminating $A$. excentricus 12 \\
\hline ØСb 13, 14, 16, 17, 18 & C. crescentus 15 & Raw sewage no. 2 \\
\hline$\varnothing \mathrm{Cb} 15$ & C. crescentus 15 & Pond water \\
\hline ØCb 23 & C. fusiformis 27 & Raw sewage no. 3 \\
\hline ØАс 20, 21, 22 & A. excentricus 48 & Raw sewage no. 3 \\
\hline
\end{tabular}

A total of 23 phage strains were isolated at the expense of five different Caulobacter and Asticcacaulis species (Table 1). Each phage strain was derived from a single enrichment culture.

Phage assays were carried out by the agar layer method of Adams (1959), with an overlayer that contained $0.4 \mathrm{ml}$. of a late exponential phase Caulobacter or Asticcacaulis culture, $0 \cdot 1 \mathrm{ml}$. phage dilution, and $2 \mathrm{ml}$. PYE agar. Plates were incubated at $30^{\circ}$.

Preparation of lysates. Attempts to obtain lysates with high phage titres from liquid cultures were not successful. Accordingly, all lysates were prepared from areas of confluent lysis in agar overlayers. The phages were eluted with $4 \mathrm{ml}$. PYE broth/ plate, and filtered. Titres of $5 \times 10^{9}$ to $5 \times 10^{10}$ plaque-forming units (p.f.u.) per ml. were obtained by this method.

Antiserum preparation and neutralization tests. Seven phages were chosen as immunizing antigens. Each appeared to be representative of a unique group of isolates or unique in itself, on the basis of source, plaque morphology and hostrange pattern. These representative phages were: ØCb 3, 6, 8r, 12r, 13, 23r, ØAc 20. Phage stocks containing at least $10^{10} \mathrm{p}$.f.u. $/ \mathrm{ml}$. were used to immunize young male albino rabbits by a series of intravenous or subcutaneous injections. Adjuvant consisting of light paraffin oil and Arlacel A (Atlas Powder Co.) was used with the subcutaneous injections. When satisfactory titres of neutralizing antibody had 
developed, the rabbits were bled by cardiac puncture and the sera stored at $-\mathbf{2 5}^{\circ}$. Neutralization tests were small according to the methods described by Adams (1959), except that mixtures were incubated at $30^{\circ}$.

Partial purification of phages. For electron microscopic examination and nucleic acid determinations, high-titre preparations of phage, free from bacterial debris, were required. Precipitation with ammonium sulphate was sometimes used to concentrate the phages, but differential centrifugation was the main method used. Crude lysates obtained by elution from confluently lysed agar overlayers were centrifuged at 6000 to $12,000 \mathrm{~g}$ for $20 \mathrm{~min}$. to eliminate bacterial debris in part. The supernatant liquid was treated with $4 \mu \mathrm{g}$. ribonuclease (California Biochemical Corp.) for $\mathbf{3 0} \mathrm{min}$. at room temperature. Most lysates were also treated with deoxyribonuclease (California Biochemical Corp.) at $4 \mu \mathrm{g} . / \mathrm{ml}$. in the presence of $0.0002 \mathrm{M}^{-} \mathrm{MgSO}_{4}$. Ammonium sulphate, when used, was added to $3 \mathrm{M}$, in the presence of $2 \mathrm{~mm}$-ethylenediaminetetra-acetic (EDTA) acid, and allowed to stand overnight at $4^{\circ}$. The precipitate was sedimented at $27,000 \mathrm{~g}$, resuspended in $0.01 \mathrm{M}$-ammonium acetate $(\mathrm{pH} 7 \cdot 4)$ and centrifuged at $6000 \mathrm{~g}$ to remove debris. The supernatant fluid was then centrifuged for $1-2 \mathrm{hr}$ at $70,000 \mathrm{~g}$ in a Spinco Model $\mathrm{L}$ ultracentrifuge. The pellets obtained were resuspended in $0.01 \mathrm{M}$-ammonium acetate, and centrifuged at 6000 or $12,000 \mathrm{~g}$. The concentrated phage suspensions

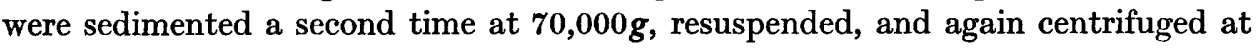
low speed. When ammonium sulphate precipitation was omitted, nuclease-treated lysates were concentrated and purified by three cycles of differential centrifugation. Approximately $\mathbf{3 0 0} \mathrm{ml}$. of crude lysate provided ample amounts of purified phage suspensions for electron-microscope preparations. In purifications for colorimetric nucleic acid determinations, 2 l. of crude lysate were used as the starting volume, and ammonium sulphate precipitation was not used.

Electron microscopy. Concentrated preparations of phages of $\varnothing \mathrm{Cb} \mathrm{3,} \mathrm{6,} \mathrm{8r,} \mathrm{12r,}$ $13,23 \mathrm{r}$ and ØAc 20 were examined by the negative staining method of Brenner \& Horne (1959) as modified by Bradley (1962). Dilutions of the phage suspensions were mixed with equal volumes of neutral $2 \%(\mathrm{w} / \mathrm{v})$ potassium phosphotungstate containing $0.4 \%(\mathrm{w} / \mathrm{v})$ sucrose, or with $1 \%(\mathrm{w} / \mathrm{v})$ uranyl acetate $(\mathrm{pH} 4.5)$, and placed on carbon-stabilized Formvar-covered electron microscope grids. Specimens were observed with a Siemens Elmiskop I operated at $80 \mathrm{kv}$.

Nucleic acid determinations. The type of nucleic acid present in $\varnothing \mathrm{Cb} 13$ and $\varnothing \mathrm{Cb} 23 \mathrm{r}$ was determined colorimetrically after extraction with $5 \%$ trichloroacetic acid. Deoxyribonucleic acid (DNA) was measured by the modified diphenylamine reaction (Burton, 1956) with deoxyadenosine (California Biochemical Corp.) as a standard. Ribonucleic acid (RNA) was estimated by the orcinol reaction (Mejbaum 1939; Schneider, 1957); standards were deoxyadenosine and purified yeast RNA (Worthington). For purposes of calculation, it was assumed that the ratio of purines to pyrimidines was $1: 1$, and that only purine-bound deoxyribose would be detected.

Another method of identifying the type of viral nucleic acid, recently described by Bradley (1965), was used with one of each of the seven serological types of caulobacter phages, and with controls of coliphages T2 and T5 obtained from Dr J. W. Banister and MS 2 obtained from Dr A. J. Clark. This method differentiates between single-stranded DNA, double-stranded DNA, and RNA. Purified phage preparations stained with acridine orange in the presence of $\mathrm{Na}_{2} \mathrm{HPO}_{4}$ and 
citrate and subsequently examined under ultraviolet irradiation give a yellow-green colour for double-stranded DNA, and orange-red with single-stranded DNA and RNA; single-stranded DNA is subsequently decolorized by treatment with citrate, while RNA retains the orange-red colour.

Sensitivity to ribonuclease. Knolle \& Kaudewitz (1963) reported that ribonuclease inhibits the lytic activity of RNA-containing phages. This phenomenon proved useful in preliminary attempts to characterize the caulobacter phages. A mixture of $10^{7}$ phage particles, $10^{7}$ host bacteria and $50 \mu \mathrm{g}$. ribonuclease was incubated at $30^{\circ}$ for 15 min., after which drops were placed on overlayers containing an inoculum of the host strain. Double controls, omitting phage and RNase, respectively, were included with each test. The inability of RNase to destroy free phage was independently established by incubating $10^{9}$ phage particles with $50 \mu \mathrm{g}$. RNase in the absence of host organisms, and determining the plaque count on appropriate dilutions.

Inactivation by ultrasonic treatment. The sensitivity of phages to ultrasonic treatment was determined by treating suspensions for 1 and $2 \mathrm{~min}$. with an ice-cooled $\frac{3}{8}$ in. probe ultrasonicator (MSE Ultrasonic Disintegrator, $60 \mathrm{~W}$. output), and determining survival by plaque count.

Phage adsorption. Broth cultures of bacteria in the exponential phase of growth were sedimented at $8000 \mathrm{~g}$ and resuspended in a small volume of adsorption medium at a concentration of about $5 \times 10^{9}$ colony-forming units $/ \mathrm{ml}$. (Among caulobacters the viable count does not accurately describe the total number of viable organisms in the population, since a large but variable proportion of the organisms occur in many-celled rosettes, each of which gives rise to a single colony on plating.) Addition of phages at a multiplicity of infection of 0.01 preceded incubation on a slow rotary shaker at $30^{\circ}$. Adsorption was followed by determining residual free phage in filtrates from samples of the incubation mixture, after 1/100 dilution and passage through a Millipore HA $(0.45 \mu)$ filter, held in a Swinney adapter. Phage lysates containing no added host organisms were filtered to determine the phage concentration at zero time and the proportion of phage passed through the filters.

Single-step growth and burst-size experiments. The procedures used were modelled after those described by Adams (1959). The temperature of incubation was $30^{\circ}$, the time allowed for phage adsorption was $15 \mathrm{~min}$., and platings were made from the growth tube at intervals of $30 \mathrm{~min}$. during 4-6 hr. Platings were made after $5 \mathrm{hr}$ in the single-burst experiments.

\section{RESULTS}

The 23 Caulobacter phages isolated fall into seven distinct groups in terms of host range and serology (Tables 2, 3). We shall refer to these groups by Roman numerals. Additional properties have in most cases been determined for only a single phage strain belonging to each group. The first six groups comprise phages isolated by enrichment with various Caulobacter species and active only against species belonging to this genus. Phages of groups I-III are DNA-containing phages which share a common gross structure and are distinctive by virtue of their unusually large particle size. They share certain similarities in their relatively wide host ranges (Table 2), and some degree of serological inter-relationship (Table 3). Phages of groups IV, V and VI are small polyhedral RNA-containing phages, closely alike in morphology but completely distinct in serology and host range. Each group of 
RNA phages has a very limited host range. The phages of group VII were isolated by enrichment with an Asticcacaulis strain, and can attack only Caulobacter strains which belong to this genus. They contain DNA, and have a morphology similar to that of many other DNA-containing bacterial viruses, such as coliphage lambda.

Table 2. Host ranges of Caulobacter and Asticcacaulis phages

\begin{tabular}{|c|c|c|c|c|c|c|c|c|}
\hline & \multicolumn{8}{|c|}{ Phage groups } \\
\hline & I & II & III & IV & $\mathbf{V}$ & $\mathbf{V a}$ & VI & VII \\
\hline & $\overbrace{\substack{\varnothing C b \\
\varnothing C b \\
3}}$ & $\begin{array}{c}\varnothing \mathrm{Cb} 6 \\
7,10 \\
11,19\end{array}$ & $\begin{array}{c}\varnothing \mathrm{Cb} 13 \\
14,16 \\
17,18\end{array}$ & 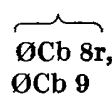 & 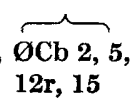 & $\varnothing \mathrm{Cb} 4$ & ØCb 23r & 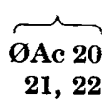 \\
\hline
\end{tabular}

\begin{tabular}{|c|c|c|c|c|c|c|c|c|}
\hline $\begin{array}{l}\text { C. vibrioides н, Св } 5 \text {, } \\
\text { Св } 18\end{array}$ & - & - & + & - & + & + & - & - \\
\hline C. vibrioides $\mathrm{G}$ & - & + & - & - & + & - & - & - \\
\hline $\begin{array}{l}\text { C. vibrioides limonus } \\
\text { CB 16, } 21\end{array}$ & - & - & + & - & - & - & - & - \\
\hline C. crescentus $\mathrm{CB} 1$ & - & - & - & - & + & + & - & - \\
\hline C. crescentus CB 2 & - & - & + & - & + & - & - & - \\
\hline C. crescentus CB 15 & - & + & + & - & + & + & - & - \\
\hline C. crescentus KA $2, \mathrm{KA}_{3}$ & + & + & + & - & + & - & - & - \\
\hline $\begin{array}{l}\text { C. henricii KA 6, СВ } 4 \text {, } \\
25,36\end{array}$ & - & - & + & - & - & - & - & - \\
\hline C. henricii СB 23 , KA 1 & - & - & - & - & - & - & - & - \\
\hline C. henricii aurantacus $\mathbf{R}$ & - & - & - & - & - & - & - & - \\
\hline $\begin{array}{l}\text { C. subvibrioides albus } \\
\text { CB } 88, \text { CB } 89\end{array}$ & - & + & - & - & - & - & - & - \\
\hline C. fusiformis Св 27,29 & - & - & - & - & - & - & + & - \\
\hline C. leidyi $\mathrm{CB} 37$ & - & - & - & - & - & - & - & - \\
\hline Type II CB 24, 26 & + & + & - & - & - & - & - & - \\
\hline C. bacteroides св 6,7 & - & + & - & - & - & - & - & - \\
\hline C. bacteroides Св 9, 10 & - & - & - & - & - & - & - & - \\
\hline C. bacteroides св 8, 11 & + & + & - & + & - & - & - & - \\
\hline Type III ka 5 & + & + & - & - & - & - & - & - \\
\hline Type IV CB 35 & - & - & - & - & - & - & - & - \\
\hline Type V CB 28 & - & - & - & - & - & - & - & - \\
\hline Bacteroid strain CB 3 & + & + & - & - & - & - & - & - \\
\hline $\begin{array}{l}\text { Vibroid strains CB } 52 \text {, } \\
54,61\end{array}$ & - & - & + & - & + & + & - & - \\
\hline Vibroid strain $\mathrm{CB} 87$ & - & - & - & + & + & - & - & - \\
\hline Henricii strain CB $\mathbf{3 4}$ & - & - & - & - & - & - & - & - \\
\hline A. excentricus AC 48 & - & - & - & - & - & - & - & + \\
\hline $\begin{array}{l}\text { A. excentricus AC 12, } \\
\text { KA } 4\end{array}$ & - & - & - & - & - & - & - & - \\
\hline Asticcacaulis s-1; C-19 & - & - & - & - & - & - & - & + \\
\hline
\end{tabular}

\section{Host ranges}

The host range of each phage was determined by placing $0.05 \mathrm{ml}$. of lysate containing $10^{7}$ to $10^{8}$ p.f.u. on an agar overlayer inoculated with the bacterial strain to be tested. Plates were examined after 18 and $48 \mathrm{hr}$. Results of tests with 23 Caulobacter phages and 46 strains of stalked bacteria are shown in Table 2 . The generic specificity of Caulobacter and Asticcacaulis phages is absolute. The Caulobacter phages of groups I, II, III and V are capable of lysing more than one species in this genus. 
The host ranges of 11 phages, representing all the Caulobacter phage groups isolated, were tested by Dr M. P. Starr against Flavobacterium (6 species), Erwinia (2 species), Xanthomonas (6 species), phytopathogenic Pseudomonas (13 species) and fluorescent soil Pseudomonas (26 species). No lytic action by the Caulobacter phages was found against any of these bacteria. Six Escherichia coli $\mathrm{F}^{-}$and $\mathrm{Hfr}$ strains were also tested as possible hosts and gave negative results.

Table 3. Antiserum neutralizaton of Caulobacter phages; first-order reaction constants

Homologous systems are indicated by bold figures.

\begin{tabular}{|c|c|c|c|c|c|c|c|c|}
\hline \multirow[b]{2}{*}{ Group } & \multirow[b]{2}{*}{ Phages } & \multicolumn{7}{|c|}{ Antiserum } \\
\hline & & $\begin{array}{c}\text { As to } \\
\varnothing 3\end{array}$ & $\begin{array}{c}\text { As to } \\
\emptyset 6\end{array}$ & $\begin{array}{c}\text { As to } \\
\varnothing 13\end{array}$ & $\begin{array}{l}\text { As to } \\
\text { Ø } 8\end{array}$ & $\begin{array}{l}\text { As to } \\
\emptyset 12\end{array}$ & $\begin{array}{l}\text { As to } \\
\emptyset 12\end{array}$ & $\begin{array}{l}\text { As to } \\
\varnothing 20\end{array}$ \\
\hline I & $\begin{array}{cc}\varnothing \mathrm{Cb} & \mathbf{1} \\
& \mathbf{3}\end{array}$ & $\begin{array}{l}258 \\
276\end{array}$ & $\begin{array}{l}\mathbf{5 4 0} \\
\mathbf{7 2 0}\end{array}$ & $\begin{array}{l}23 \\
15\end{array}$ & $\begin{array}{l}<1 \\
<1\end{array}$ & $\begin{array}{l}<1 \\
<1\end{array}$ & $\begin{array}{l}<1 \\
<1\end{array}$ & $\begin{array}{l}<1 \\
<1\end{array}$ \\
\hline II & $\begin{array}{rr}\varnothing \mathrm{Cb} & 6 \\
7 \\
10 \\
11 \\
19\end{array}$ & $\begin{array}{l}46 \\
52 \\
42 \\
44 \\
40\end{array}$ & $\begin{array}{l}4000 \\
3500 \\
3140 \\
\mathbf{3 7 6 0} \\
\mathbf{4 5 0 0}\end{array}$ & $\left.\begin{array}{l}17 \\
24 \\
18 \\
13 \\
12\end{array}\right\}$ & All < 1 & All $<1$ & All $<1$ & All $<1$ \\
\hline III & $\left.\begin{array}{r}\varnothing \mathrm{Cb} 13 \\
14 \\
16 \\
17 \\
18\end{array}\right\}$ & All $<1$ & $\left\{\begin{array}{l}200 \\
170 \\
123 \\
205 \\
220\end{array}\right.$ & $\left.\begin{array}{l}154 \\
154 \\
130 \\
133 \\
180\end{array}\right\}$ & All $<1$ & All $<1$ & All $<1$ & All $<1$ \\
\hline IV & $\begin{array}{cl}\varnothing \mathrm{Cb} & 8 \mathbf{r} \\
& 9\end{array}$ & $\begin{array}{l}<1 \\
<1\end{array}$ & $\begin{array}{l}<1 \\
<1\end{array}$ & $\begin{array}{l}<1 \\
<1\end{array}$ & $\begin{array}{l}690 \\
746\end{array}$ & $\begin{array}{l}<1 \\
<1\end{array}$ & $\begin{array}{l}<1 \\
<1\end{array}$ & $\begin{array}{l}<1 \\
<1\end{array}$ \\
\hline $\mathbf{V}$ & $\left.\begin{array}{cc}\varnothing \mathrm{Cb} & 2 \\
4 \\
5 \\
12 \mathrm{r} \\
15\end{array}\right\}$ & All $<1$ & All $<1$ & All $<1$ & All $<1$ & $\left.\begin{array}{l}346 \\
102 \\
386 \\
460 \\
330\end{array}\right\}$ & All $<1$ & All $<1$ \\
\hline VI & $\varnothing \mathrm{Cb} 23 \mathrm{r}$ & $<1$ & $<1$ & $<1$ & $<1$ & $<1$ & 1450 & $<1$ \\
\hline VII & 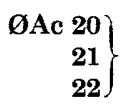 & All $<1$ & All $<1$ & All $<1$ & All $<1$ & All $<1$ & All $<1$ & $\left\{\begin{array}{l}2860 \\
2880 \\
2580\end{array}\right.$ \\
\hline
\end{tabular}

\section{Serology}

The results of the antiserum neutralization tests are shown in Table 3, expressed as first order reaction constants. It was possible to place the 23 phage isolate into seven serological groups. The pre-immune sera, included as controls, gave constants of less than 1 with homologous immunizing antigens, indicating that no 'normal' neutralizing antibodies were present before immunization had begun. The constant for phage $\emptyset \mathrm{Cb} 4$ with antiserum 12 is somewhat lower than those obtained with the other phages of group $\mathrm{V}$; the host range pattern of phage $\varnothing \mathrm{Cb} 4$ also differs slightly from that of phages $Ø \mathrm{Cb} 2 \mathrm{r}, 5 \mathrm{r}, 12 \mathrm{r}$ and $15 \mathrm{r}$. The phages of groups I, II and III show distant serological cross-relationships to each other. In an exceptional case, antiserum to phage $\varnothing \mathrm{Cb} 3$ (group I) did not neutralize plaque-forming ability of phages of group III to any measurable extent, but in the reciprocal tests, antiserum to 
phage $\varnothing \mathrm{Cb} 13$ (group III) neutralized phages of group I. The remainder of the phages, which make up groups IV, V, VI and VII, were not neutralized by antisera to any other groups.

\section{Electron microscopy of phages}

Caulobacter phage $Ø \mathrm{Cb} 13$ is shown in $\mathrm{Pl}$. 1, fig. 1. It possesses an unusually large and elongated head. The dimensions of an intact phage head are $170 \times 50 \mathrm{~m} \mu$; tails are 200-250 $\mathrm{m} \mu$ in length. Plate 1, fig. 2, shows structures that are interpreted to be cross-sectional fragments of the phage $\varnothing \mathrm{Cb} 13$ tail. The hollow core is observable. The outer diameter of the cross-section is about $10 \mathrm{~m} \mu$, in agreement with the width of the intact tail. Apices of the head structure can be observed in the empty heads of preparations precipitated with ammonium sulphate (Pl. 1, fig. 3). Most of the $\varnothing \mathrm{Cb} 13$ particles in such preparations were inactivated, having been subjected to osmotic shock, and appear as tailless empty heads. Phages ØCb 3 and 6 are similar in morphology to ØCb 13.

Caulobacter phage ØCb 23r is shown in $\mathrm{Pl}$. 1, fig. 4. It has a diameter of $21-23 \mathrm{~m} \mu$ and no tail has been observed. Morphologically it resembles the coliphage R-17 (Crawford \& Gesteland, 1964). In Pl. 1, fig. 4, the narrow filaments to which the phage particles adhere may be DNA fibres, since they could be removed from the preparations by treatment with deoxyribonuclease. Phages ØCb $8 \mathrm{r}$ (Pl. 1, fig. 5) and ØCb $12 \mathrm{r}$ are similar in size $(22-23 \mathrm{~m} \mu$ diameter) to phage ØCb $23 \mathrm{r}$ and also do not appear to have tails. Phosphotungstate stains of these two phages caused most phage particles to lose their structural integrity, and very few intact phage particles could be identified in such preparations. However, uranyl acetate stains gave satisfactory results.

Plate 2, fig. 6, shows Asticcacaulis phage ØAc 20; the hexagonal shape of the ØAc 20 head is more evident in empty particles. A circular electron-transparent area can be seen just inside the hexagonal boundary of many of the empty heads, and is probably due to the way in which the protein coat of the head collapsed after becoming emptied of its nucleic acid. Most of the empty heads lack a tail. The dimensions of the intact phage head are $65 \times 70 \mathrm{~m} \mu$, and the tail is $150 \mathrm{~m} \mu$ in length.

\section{Phage-plaque morphology}

Four distinct plaque morphologies, shown in Pl. 2, figs. 7-10, were seen among the seven phage groups. Phages $Ø \mathrm{Cb} 3$ and 6 with their host Caulobacter bacteroides strain 11 , and phage $Ø \mathrm{Cb} 13$ with its host $C$. crescentus strain 15 gave clear plaques with a diameter of 0.5 to $1 \mathrm{~mm}$. (Pl. 2, fig. 7). Phage ØAc 20 also produced clear plaques but these were extremely minute, with an average diameter of less than $0.5 \mathrm{~mm}$. (Pl. 2, fig. 8). Phages ØCb 8r, 12r and $23 \mathrm{r}$ produced cloudy diffuse plaques on their respective host strains. The plaque sizes of phages $\varnothing \mathrm{Cb} 8 \mathrm{r}$ and $\varnothing \mathrm{Cb} 23 \mathrm{r}$ (Pl. 2, fig. 9) varied from 0.5 to $2 \mathrm{~mm}$. in diameter, but despite their cloudy character were not difficult to detect. Phage $\varnothing \mathrm{Cb} 12 \mathrm{r}$ and phages related to it $(\varnothing \mathrm{Cb} 2 \mathrm{r}, 4 \mathrm{r}, 5 \mathrm{r}$, 15r) formed extremely cloudy plaques (Pl. 2, fig. 10).

\section{Nucleic acid determinations}

The results of colorimetric analysis of purified preparations of phage $\varnothing \mathrm{Cb} 13$ showed that all the orcinol-reacting material present could be ascribed to the presence of DNA as determined by the diphenylamine reaction. The other phage 
tested by these procedures, $\varnothing \mathrm{Cb} 23 r$, contained only RNA; no DNA was detectible in purified preparations of it.

The results of the acridine orange-staining technique are shown in Table 4.

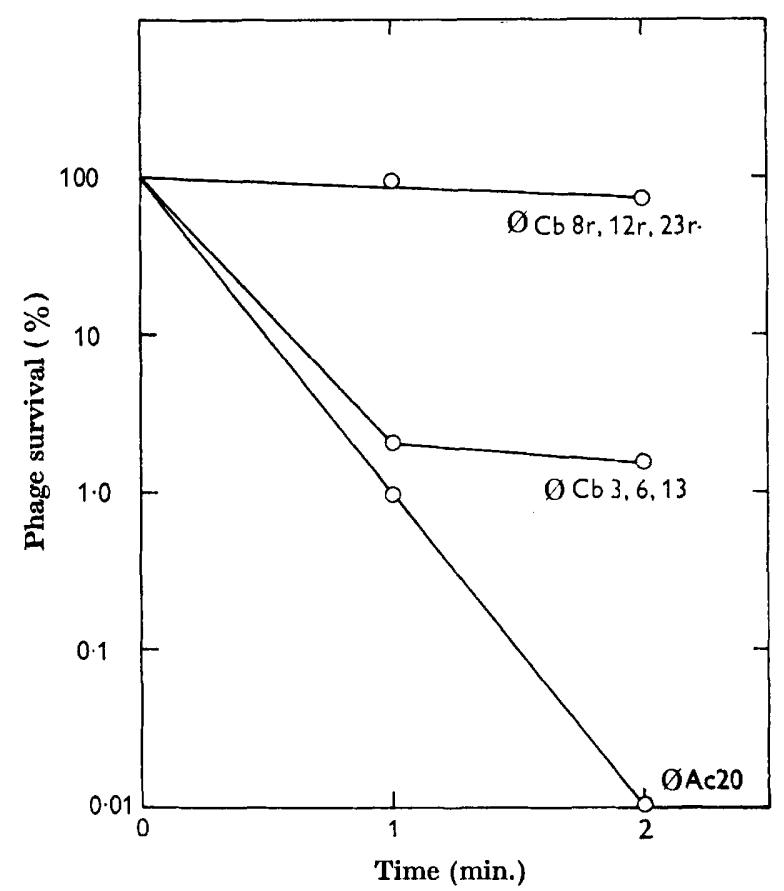

Fig. 1. Inactivation of Caulobactor phages by ultrasonic treatment.

Table 4. Results of acridine orange colour test (Bradley, 1965) for nucleic acid identification in Caulobacter and other phages

\begin{tabular}{|c|c|c|c|c|}
\hline Phage & Group* & $\begin{array}{l}\text { Primary acridine } \\
\text { orange reaction }\end{array}$ & $\begin{array}{c}\text { Decolorization } \\
\text { with } \\
0 \cdot 1 \text { M-citrate }\end{array}$ & $\begin{array}{l}\text { Nucleic } \\
\text { acid }\end{array}$ \\
\hline ØAc 20 & VII & Yellow-green & & DNA \\
\hline$\emptyset \mathrm{Cb} 3$ & I & Yellow-green & & DNA \\
\hline$\varnothing \mathrm{Cb} 6$ & II & Yellow-green & & DNA \\
\hline ØCb 18 & III & Yellow-green & & DNA + \\
\hline T 2 (control) & III & Yellow-green & & DNA \\
\hline T 5 (control) & III & Yellow-green & & DNA \\
\hline ØCb 8r & IV & Orange-red & - & RNA \\
\hline$\emptyset \mathrm{Cb} 12 \mathrm{r}$ & $\mathbf{v}$ & Orange-red & - & RNA \\
\hline ØCb 23r & VI & Orange-red & - & RNA $\dagger$ \\
\hline MS 2 (control) & & Orange-red & - & RNA \\
\hline
\end{tabular}

* See Tables $2,3$.

$\dagger$ Nucleic acid also identified by other colorimetric methods.

\section{Phage inactivation}

The plaque-forming ability of phages $\varnothing \mathrm{Cb} 8 \mathrm{r}, 12 \mathrm{r}$ and $23 \mathrm{r}$ was inhibited by ribonuclease in the presence of host bacteria. However, when the phages were exposed to RNase in the absence of the host, followed by dilution before plating, phage inactivation did not result. The other phages tested were resistant to RNase. 
The small RNA phages (ØCb $8 \mathrm{r}, 12 \mathrm{r}, 23 \mathrm{r}$ ) which seem to lack tails, were more resistant to inactivation by ultrasonic treatment than were tailed phages (Fig. 1). The three large phages $(\varnothing \mathrm{Cb} \mathrm{3,6,13)}$ which resemble each other morphologically also have similar ultrasonic inactivation curves. These three phages, which have flexible tails, were less sensitive than was phage ØAc 20, which has a relatively rigid tail. Marvin \& Hoffman-Berling (1963) studied the sensitivity of phages to ultrasonic treatment in relation to their structure; filamentous phages and phages with tails were much more sensitive to ultrasonic treatment than were the polyhedral phages lacking tails, such as fr. Caulobacter phages $\varnothing \mathrm{Cb} 8 \mathrm{r}, 12 \mathrm{r}$ and 23r, examined in the present work, gave results similar to the polyhedral phages studied by Marvin \& Hoffman-Berling (1963).

None of the Caulobacter phages was sensitive to chloroform. Only phages $\varnothing \mathrm{Cb} 8 \mathrm{r}$ and $23 \mathrm{r}$ withstood osmotic shock following exposure to $10 \% \mathrm{NaCl}$. In heat-inactivation experiments phage $\varnothing \mathrm{Cb} 12 \mathrm{r}$ was inactivated by exposure to $40^{\circ}$ for $1 \mathrm{hr}$, while phages $\varnothing \mathrm{Cb} 3$ and $8 \mathrm{r}$ were stable at that temperature. Higher temperatures caused inactivation of all three phages. Phages $\varnothing \mathrm{Cb} \mathrm{3,8r}, 12 \mathrm{r}$ and 13 were inactivated by $0.02 \mathrm{M}$-phosphate buffer $(\mathrm{pH} 7)$ and by $0.02 \mathrm{M}$-tris-(hydroxymethyl)-aminomethane buffer (Sigma 121; pH 7).

\section{Adsorption of Caulobacter phages}

Results of phage adsorptions done in the presence of 0.002 or $0.004 \mathrm{M}-\mathrm{MgSO}_{4}$ are shown in Table 5. Because the concentrations of caulobacters in the adsorption mixtures could not be accurately determined because of rosette formation, firstorder reaction constants were not calculated. The use of filtration to obtain unadsorbed phage particles was preferable to the removal of adsorbed phages by sedimentation, since stalked caulobacters and rosettes were difficult to sediment

Table 5. Phage adsorption to Caulobacter and Asticcacaulis strains

\begin{tabular}{|c|c|c|c|c|c|c|}
\hline \multirow[b]{2}{*}{ Phage } & \multirow[b]{2}{*}{ Group* } & \multirow[b]{2}{*}{ Host } & \multicolumn{4}{|c|}{ Free phage at time (min. } \\
\hline & & & $\begin{array}{c}\mathrm{MgSO}_{4} \\
\text { cencentration } \\
\text { (M) }\end{array}$ & 2 & $\begin{array}{r}5 \\
\text { ee } p\end{array}$ & 10 \\
\hline$\emptyset \mathrm{Cb} \quad 3$ & $\mathbf{I}$ & C. bacteroides 11 & 0.002 & 51 & 30 & 19 \\
\hline$\emptyset \mathrm{Cb} 3$ & $\mathbf{I}$ & C. bacteroides 11 & $0 \cdot 004$ & 22 & 14 & 10 \\
\hline ØCb 6 & II & C. bacteroides 11 & $0 \cdot 002$ & 75 & 47 & $\mathbf{3 5}$ \\
\hline ØCb 6 & II & C. bacteroides 11 & $0 \cdot 004$ & 32 & 22 & 14 \\
\hline ØCb 13 & III & C. crescentus 15 & $0 \cdot 004$ & 35 & 19 & 10 \\
\hline ØCb 8r & IV & C. bacteroides 11 & 0.002 & 18 & 6 & 4 \\
\hline$\emptyset \mathrm{Cb} 12 \mathrm{r}$ & $\mathbf{v}$ & C. crescentus 15 & $0 \cdot 002$ & $\mathbf{5 5}$ & $\mathbf{3 1}$ & 25 \\
\hline$\emptyset \mathrm{Cb} 23 r$ & VI & C. fusiformis 27 & 0.002 & 40 & 28 & 21 \\
\hline ØAc 20 & VII & A. excentricus & $0 \cdot 002$ & 50 & 46 & 43 \\
\hline
\end{tabular}

quantitatively. The presence of rosettes also prevented determination of numbers of infected caulobacters as an efficient measure of adsorption, since more than one caulobacter per large rosette might be infected, but the rosette would plate as only one infective centre. Since most of the Caulobacter phages were adequately absorbed 
within 15 min. after their addition, single-step growth experiments could be done satisfactorily, and the optimal adsorption conditions for each phage were not determined.
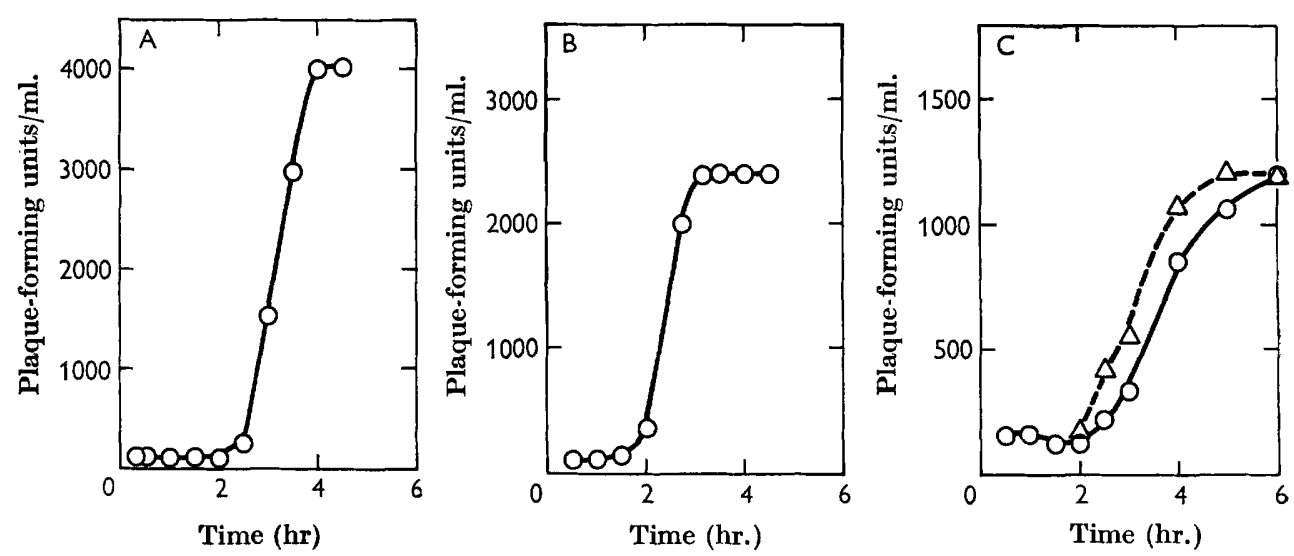

Fig. 2. Single-step growth curves of phages on Caulobacter hosts. A. phage $\emptyset \mathrm{Cb} 8 \mathrm{r}$, on C. bacteroides 11 ; B. phage $\emptyset \mathrm{Cb} 13$ on $C$. vibrioides 15 ; C. phage ØAc 20 on $A$. excentricus 48. $\mathrm{O}-\mathrm{O}$, infective centres: $\triangle \cdots \Delta$, chloroform treatment.

Table 6. Latent period and burst sizes of selected Caulobacter phages

\begin{tabular}{|c|c|c|c|c|c|}
\hline Phage & Group* & Host & $\begin{array}{l}\text { Phage } \\
\text { latent } \\
\text { period } \\
\text { (min.) }\end{array}$ & $\begin{array}{c}\text { Host } \\
\text { generation } \\
\text { time } \\
\text { (min.) }\end{array}$ & $\begin{array}{c}\text { Burst } \\
\text { size }\end{array}$ \\
\hline$\varnothing \mathrm{Cb} 3$ & I & C. bacteroides 11 & 150 & 215 & 10 \\
\hline$\varnothing \mathrm{Cb} 6$ & II & C. bacteroides 11 & 150 & 215 & 8 \\
\hline ØCb 13 & III & C. crescentus 15 & 105 & 108 & . \\
\hline DAc 20 & VII & A. excentricus 48 & 150 & 120 & . \\
\hline$\varnothing \mathrm{Cb} 8 \mathbf{r}$ & IV & C. bacteroides 11 & 150 & 215 & 33 \\
\hline$\varnothing \mathrm{Cb} 12 \mathrm{r}$ & $\mathbf{V}$ & C. crescentus 15 & 150 & 108 & 22 \\
\hline$\varnothing \mathrm{Cb} 23 \mathrm{r}$ & VI & C. fusiformis 27 & 180 & 300 & 14 \\
\hline
\end{tabular}

Single-step growth and single-burst experiments

A summary of data obtained from single-step growth and single-burst experiments is shown in Table 6. The latent period of all the Caulobacter phages tested was relatively long ( $2 \mathrm{hr}$ or more) and the burst sizes were very small. Single-step growth curves are shown for three representative Caulobacter phages in Fig. 2. In the phage ØAc 20 single-step growth experiment, the curve in which samples were exposed to $5 \%$ chloroform represents mature intracellular phage particles in addition to phage particles already released in normal bursts.

\section{DISCUSSION}

It is notable that the first systematic search for phages active against caulobacters has yielded, out of a total of 23 strains, no less than eight phages which contain RNA. Furthermore, these eight phages fall into three entirely distinct 
serological groups, and are also readily distinguishable from one another in terms of specific host ranges. Hitherto, only two species of bacteria have been reported to serve as hosts for RNA-containing viruses: Escherichia coli (Loeb \& Zinder, 1961; Dettori, Maccacaro \& Piccinin, 1961; Davis \& Sinsheimer, 1963; Marvin \& Hoffman-Berling, 1963; Crawford \& Gesteland, 1964; Bradley, 1964), and Pseudomonas aeruginosa (Feary, Fisher \& Fisher, 1963). These facts suggest that the natural phage populations active against Caulobacter species may contain an unusually large proportion of RNA viruses.

The discovery of three new types of RNA-containing phage provides a somewhat broader basis for drawing conclusions about the properties of this interesting category of bacterial viruses. Like the types which have been earlier described, the RNA phages active against caulobacters are small (21-23 $\mathrm{m} \mu$ in diameter) and apparently simple in structure. All of them share the property of susceptibility to the action of RNase in the presence of host bacteria, a character which Knolle \& Kaudewitz (1963) claimed to be useful in determining the type of nucleic acid present in newly-isolated phages.

One of the initial goals of our work was to obtain a viral system that might be used to mediate gene transfer in the Caulobacter group. To this end, several attempts were made to detect lysogeny in Caulobacter and Asticcacaulis strains, particular attention being given to those strains which were resistant to the virulent phages which had been isolated. Such strains were exposed to ultraviolet irradiation and subsequently incubated in growth medium for several hours, after which filtrates were plated on randomly selected potential indicator strains. No evidence of lysogeny was detected. Attempts to use Caulobacter phage ØAc 20 to lysogenize its host Asticcacaulis excentricus strain 48, also failed. Following exposure of this host to phage ØAc 20, many phage-resistant clones were isolated, but none of the purified phage-resistant strains yielded detectable phage ØAc 20 particles after ultraviolet irradiation.

\section{Taxonomic implications}

The caulobacters are a group of Gram-negative polarly-flagellate bacteria, until recently little known, and distinguishable from other bacteria that conform to this general description only by their ability to form cellular stalks and to secrete holdfasts. The study of the group by Poindexter (1964), based on a detailed comparative analysis of many pure cultures, led for the first time to an understanding of their biological properties. Poindexter's work showed that in many physiological respects the caulobacters resemble the aerobic chemoheterotrophic pseudomonads. At the same time, studies on their development (Poindexter, 1964; Stove \& Stanier, 1962) showed that stalk formation is not a facultative phenomenon, but a morphogenetic event intimately geared with the process of cell division: in effect, no caulobacter can divide until it has formed a stalk. There is, accordingly, a deep difference in the reproductive cycle between the caulobacters and all other eubacteria of the pseudomonas line. On these and other grounds, Poindexter (1964) recommended the retention of a special family, the Caulobacteraceae, for these organisms. In this context, phage specificity is relevant. Dr M. P. Starr \& Mrs G. R. Cosens (personal communication) have tested our Caulobacter phages against many strains of Pseudomonas, Xanthomonas and Erwinia, and we have tested them against strains 
of Escherichia coli. In no case has lytic activity been observed. Conversely, Dr Starr \& Mrs Cosens have tested 65 phages active against members of the Pseudomonas Xanthomonas and Erwinia groups on 60 representative isolates of Caulobacter, with completely negative results. Thus far, therefore, the caulobacters emerge as a completely isolated group with respect to host/phage interactions.

In the family Caulobacteraceae, Poindexter recognized two genera: the original genus Caulobacter Henrici and Johnson, and a new genus, Asticcacaulis. In Asticcacaulis strains, there is a topological separation between stalk and holdfast. While the holdfast occupies the same position as in the caulobacters, at one pole of the cell, the stalk develops as a lateral rather than as a polar extrusion, and consequently does not have holdfast material at its base. Base ratio analyses of DNA from Caulobacter and Asticcacaulis strains, performed by Dr M. Mandel (Poindexter, 1964) also revealed significant differences. The moles per cent of guanine + cytosine in eight Caulobacter strains ranged from 62 to 67 , substantially coinciding with the range characteristic of aerobic pseudomonads; the value obtained for one Asticcacaulis strain was 55, significantly lower than the values either for Caulobacter species or for the aerobic pseudomonads. As we have shown, there appears to be an absolute separation between these two genera of stalked bacteria with respect to host specificity for bacteriophages: none of our numerous phages active against members of the Caulobacter group lysed any strain of Asticcacaulis, and the group of phages active against Asticcacaulis was unable to lyse any of the Caulobacter strains. Accordingly, Poindexter's general taxonomic conclusions on the stalked bacteria are very well supported by the results of the present study.

We wish to thank Dr J. H. McAlear, Director of the Electron Microscope Laboratory, for his helpful advice and Mr Philip Spencer for his preparation of the phage photographs. One of us (J.M.S.) was supported by a National Institutes of Health Traineeship.

\section{REFERENCES}

Adams, M. (1959). Bacteriophages. New York: Interscience Publishers, Inc.

Bradley, D. E. (1962). A study of the negative staining process. J. gen. Microbiol. 29, 503.

Bradley, D. E. (1964). The structure of some bacteriophages associated with male strains of Escherichia coli. J. gen. Microbiol. 35, 471.

Bradley, D. E. (1965). The staining of bacteriophage nucleic acids with acridine orange. Nature, Lond. 205, 1230.

Brenner, S. \& Horne, R. W. (1959). A negative staining method for high resolution electron microscopy of viruses. Biochim. biophys. Acta, 34, 103.

Burton, K. (1956). A study of the conditions and mechanism of the diphenylamine reaction for the colorimetric estimation of deoxyribonucleic acid. Biochem. J. 62, 315.

Crawford, E. M. \& Gesteland, R. F. (1964). The adsorption of bacteriophage R-7. Virology, 22, 165.

Davis, J. E. \& Sinsheimer, R. L. (1963). The replication of bacteriophage MS 2. 1. Transfer of parental nucleic acid to progeny phage. J. molec. Biol. 6, 203.

Dettori, R., Maccacaro, G. A. \& Piccinin, G. L. (1961). Sex-specific bacteriophages of Escherichia coli к12. G. Microbiol. 9, 141.

Feary, T., Fisher, E., Jr. \& Fisher, T. (1963). A small RNA-containing Pseudomonas aeruginosa bacteriophage. Biochem. biophys. Res. Commun. 10, 359.

Khavina, E. S. \& RaUtenstein, A. I. (1963). A bacteriophage for cultures of bacteria of the genus Caulobacter. Doklady Akad. Nauk U.S.S.R. 153, 197. 

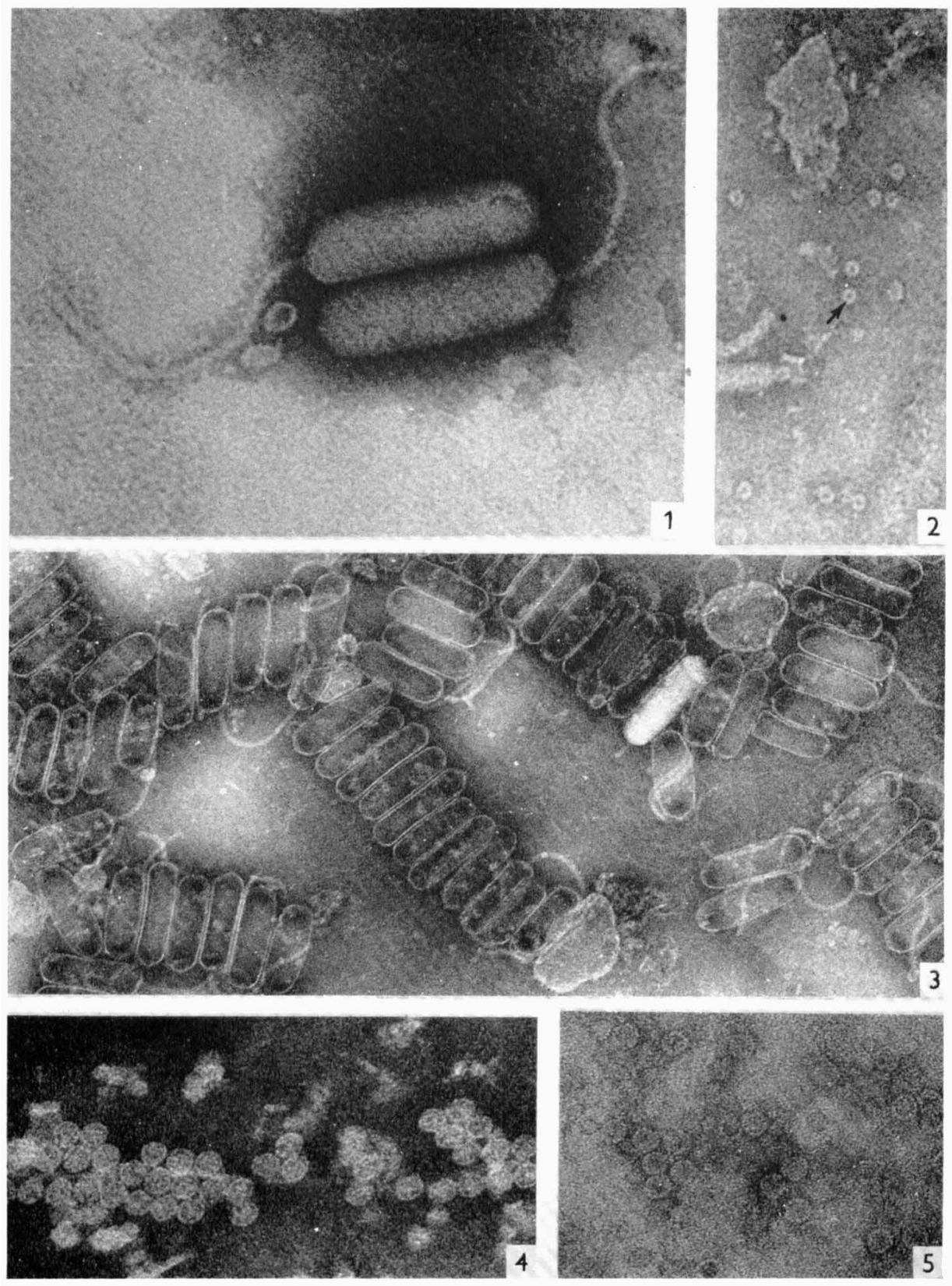

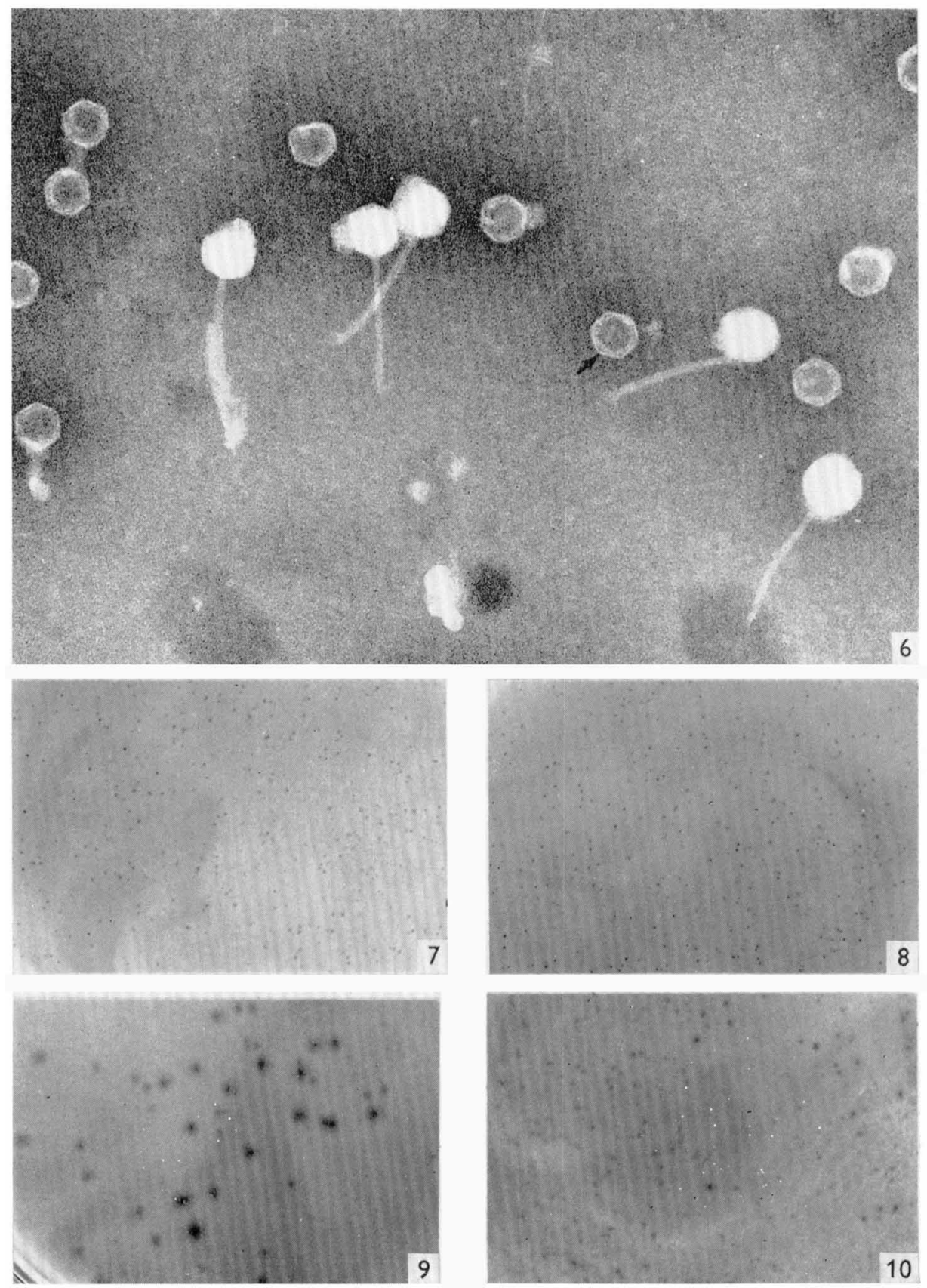

J. M. SCHMIDT AND R. Y. STANIER 
KNolde, P. \& KAUdewitz, F. (1963). Effect of RNase pretreatment of cells of Escherichia coli $\mathrm{k} 12$ on plaque yields resulting from subsequent infection with the RNA phage fr. Biochem. biophys. Res. Commun. 11, 383.

Loeb, T. \& Zinder, N. (1961). A bacteriophage containing RNA. Proc. nat. Acad. Sci., Wash. 47, 282.

Marvin, D. A. \& Hoffman-Berling, A. (1963). Physical and chemical properties of two new small bacteriophages. Nature, Lond. 197, 517.

Mejbaum, W. (1939). Uber die Bestimmung kleiner Pentosemenger, insbesondere in Derivaten der Adenylsäure. Z. physiol. Chem. 258, 117.

Poindexter, J. S. (1964). Biological properties and classification of the Caulobacter group. Bact. Rev. 28, 231.

Schnemer, W. C. (1957). Determination of nucleic acids in tissues by pentose analysis. Meth. Enzym. 3, 680.

Stove, J. L. \& Stanier, R. Y. (1962). Cellular differentiation in stalked bacteria. Nature, Lond. 196, 1189.

\section{EXPLANATION OF PLATES}

Plate 1

Fig. 1. Caulobacter phage $\emptyset \mathrm{Cb} 13$. Intact phage particles. Phosphotungstate stain. $\times 200,000$.

Fig. 2. Caulobacter phage $Ø \mathrm{Cb} 13$. Cross-sectional fragments of phage tails. Phosphotungstate stain. $\times 200,000$.

Fig. 3. Caulobacter phage $\emptyset \mathrm{Cb} 13$. Phage preparation inactivated with ammonium sulphate precipitation. $\times 96,000$.

Fig. 4. Caulobacter phage $Ø \mathrm{Cb}$ 23r. Phosphotungstate stain. $\times 160,000$.

Fig. 5. Caulobacter phage $\emptyset \mathrm{Cb} 8$ r. Uranyl acetate stain. $\times 160,000$.

Plate 2

Fig. 6. Asticcacaulis phage ØAc 20. Phosphotungstate stain. Arrow: empty head with interior electron-transparent ring. $\times 120,000$.

Figs. 7-10. Caulobacter phage plaque morphology. $\times 1$.

Fig. 7. ØCb 13 plated on $C$. crescentus strain 15.

Fig. 8. ØAc 20 plated on $A$. excentricus 48.

Fig. 9. ØCb 8r plated on $C$. bacteroides 11 .

Fig. 10. $\oslash \mathrm{Cb} 12 \mathrm{r}$ plated on $C$. crescentus strain 15. 